Thorax (1956), 11, 328.

\title{
SURGERY IN THE TREATMENT OF PULMONARY TUBERCULOSIS IN PATIENTS AGED 50 AND OVER
}

\author{
BY \\ ARNOLD PINES AND RICHARD ROWLANDSON \\ From the London Chest Hospital and the London Hospital
}

(RECEIVED FOR PUBLICATION APRIL 10, 1956)

Over the past 15 years there has been a remarkable change in the age incidence of pulmonary tuberculosis. In men, an increasing number of newly diagnosed patients have been aged 45 years and over, and their treatment has assumed great importance (Simmonds, 1953 ; Ellman, 1956). In women, this change has been much less marked, but the tendency can still be noted.

This increasing preponderance of older men has been noted in many public health reports, for example, that for Scotland (1954), Middlesex (1954), Northamptonshire (1954), Manchester (1954), and Liverpool (1953). Mass radiography reports show the same change over the whole of Great Britain (Ministry of Health report, 1954), while similar trends have been noted in other countries, for example, the United States of America (New York State Department of Health, 1954), France (Ministère de la Santé Publique, 1954), Canada (Beaconsfield, Coulthard, and Kergin, 1954), and Italy (Pines, 1955).

The problem is intensified by the proven higher natural mortality from tuberculosis of these older patients (Alling, Lincoln, and Bosworth, 1954 and 1955 ; Caplin, Griffiths, and Silver, 1956). In England and Wales in 1940 mortality from tuberculosis was highest amongst those aged 20-25 years, but by 1953 this had been more than halved. In contrast the mortality among those aged 45 to 59 has remained stationary and perhaps even increased, and certainly in 1953 the majority of deaths in male phthisical subjects occurred in this age group (Registrar-General's Statistical Review of England and Wales, 1940-1953). Similar trends are shown in most of the reports mentioned above. Again, relapse has been shown to increase with the age of patients till at the age of 60 it is more than double that at the age of 25 (Oyama, 1955).

The factors which lie behind these trends in morbidity and mortality are obscure and little investigated. But among the most significant may well be the more cautious and timid approach which is made to the treatment of these older patients, particularly when the question of surgical intervention arises. Among recent advocates of such surgical caution, one authority may be quoted: "Except in special circumstances, it is unwise to embark upon an active therapy programme over the age of 50, particularly if major surgical procedures are likely to be required "(Pagel, Simmonds, and Macdonald, 1953). That this opinion is widespread is shown by the proportion of patients in various age groups in the recent Society of Thoracic Surgeons Survey for the British Tuberculosis Association (1955): only 31 of those patients admitted to surgery in the year 1953 were aged 54 years and over out of the 3,183 operations recorded.

It is in the light of the increasing seriousness of the problem of these older patients and of the frequent denial to them of essential surgery that we have attempted a retrospective survey of those aged 50 and over who have had major operations for pulmonary tuberculosis in the London Chest Hospital. In addition we have included 10 patients under the care of $\mathrm{Mr}$. Vernon $\mathrm{C}$. Thompson at the London Hospital.

\section{Material}

The notes and radiographs were obtained of all those patients aged 50 and over who had been treated between 1947 and 1954, together with a report on their full progress since surgery and any recent or relevant radiographs. Most were still attending follow-up clinics at one or other of the hospitals, and in the remainder a report on their well-being with radiographs was given by the chest physician looking after them. Details extracted concerned various points which are dealt with below.

The patients themselves sometimes came from home, where they had undergone domiciliary preparation, others had received preliminary medical treatment at the two hospitals, but the majority had received such treatment at other hospitals or sanatoria, and were transferred back 
to their original hospital at a suitable time after surgery had been completed. The remainder were graded in both hospitals and discharged home four to seven hours after grading, returning to clinic supervision.

One hundred and twenty suitable case records have been considered, 110 from the London Chest Hospital and 10 from the London Hospital. Nine cases have eluded full follow-up and have been discarded from the figures quoted in the tables, but none of these had died up to the time they were lost sight of. Twenty-eight were women and 83 were men. All except 12 received varying short courses of anti-tuberculosis drugs.

\section{Pre-operative Disease State and Mortality}

Table I summarizes the state of the patients before operation and the relation of various features to prognosis. The grading of the disease state follows that of the National Tuberculosis Association (1950). The cavitation figures refer to the presence of cavities at any time pre-operatively, not necessarily in the last pre-operative film. Dyspnoea was graded conveniently into three broad groups, namely, (1) dyspnoea on moderate exertion, (2) dyspnoea on slight exertion, and (3) dyspnoea at rest. Death post-operatively means death within six months of operation.

Bronchitis and emphysema are discussed later.

TABLE I

PRE-OPERATIVE DISEASE STATE AND MORTALITY

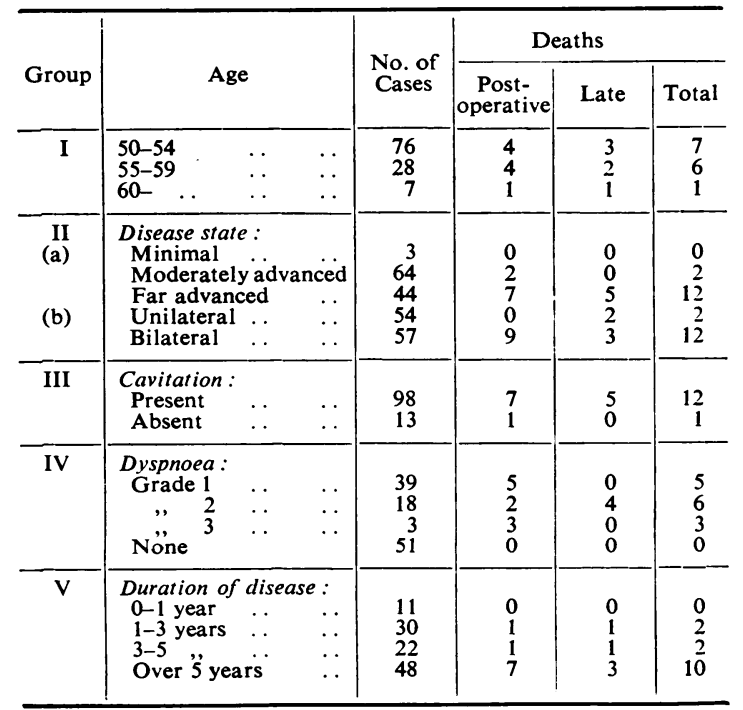

The mortality in those aged 55-59 years was more than twice that found in the younger group. However, very many of this group had been under observation for five years or more and their prognosis was correspondingly far worse (Mitchell, 1955). Therefore it is very probable that age in itself was relatively unimportant.

The extent of the disease is a predominating factor as is well known (Foster-Carter, Myers, Goddard, Young, and Benjamin, 1952 ; Mitchell, 1955), and the presence or absence of cavitation reflects the same tendency. But the main factor appears to us to be the degree of dyspnoea. No patient without dyspnoea died, while all three with grade 3 dyspnoea died and the intermediate groups showed the same trend. Similarly associated bronchitis was often, but not invariably, of importance, as will be shown later.

The extent of the disease affects the degree of dyspnoea of the individual, but it appears to us that it was the dyspnoea in itself that mattered when the question of survival arose in this series.

Many patients had been admitted several times to various hospitals previously, and in some the prospect of surgery had been formerly rejected by those responsible for their treatment, the major contraindication being held to be age. All these combined features suggest that the whole comprised a more severely affected and disabled group than those met in most surgical centres.

No patient was operated upon who had evidence of myocardial insufficiency. Ten had varying degrees of hypertension; a diastolic blood pressure of $120 \mathrm{~mm}$. of mercury was recorded in two cases. Five had diabetes and in three peptic ulceration was present. None of these diseases appeared to affect the post-operative course except in two cases of the latter.

The type and number of operations performed are shown in Table II.

TABLE II

TYPE AND NO. OF OPERATIONS

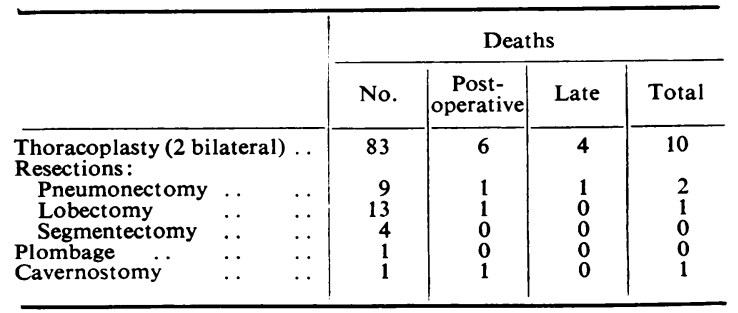

The indications for the various operations followed orthodox lines in general. Latterly, the importance of preserving lung function in these patients became obvious and certain modifications both of procedure and assessment were developed. Thus only in a few instances have more than five 
TABLE III

ANALYSIS OF FATAL CASES

\begin{tabular}{|c|c|c|c|c|c|c|c|c|c|c|}
\hline \multirow{2}{*}{$\begin{array}{l}\text { Case } \\
\text { No. }\end{array}$} & \multirow[b]{2}{*}{ Age } & \multirow{2}{*}{$\begin{array}{l}\text { Location } \\
\text { of Disease }\end{array}$} & \multirow{2}{*}{$\begin{array}{l}\text { Disease } \\
\text { State }\end{array}$} & \multirow{2}{*}{$\begin{array}{l}\text { Duration } \\
\text { of Disease } \\
\text { in Years }\end{array}$} & \multirow{2}{*}{$\begin{array}{l}\text { Cavity } \\
\text { Present }\end{array}$} & \multirow{2}{*}{$\begin{array}{c}\text { Dyspnoea } \\
\text { Grade }\end{array}$} & \multirow[b]{2}{*}{ Bronchitis } & \multicolumn{2}{|c|}{ Death } & \multirow[b]{2}{*}{ Cause } \\
\hline & & & & & & & & $\begin{array}{c}\text { Post- } \\
\text { operative }\end{array}$ & Late & \\
\hline \multirow{2}{*}{\multicolumn{2}{|c|}{$\begin{array}{l}\text { Thoracoplasty } \\
1\end{array}$}} & & & & & & & & & \\
\hline & $55-59$ & Bilateral & $\begin{array}{l}\text { Moderately } \\
\text { advanced }\end{array}$ & -3 & + & 1 & + & 1 & & $\begin{array}{l}\text { Pulmonary embolus } 11 \text { th } \\
\text { day }\end{array}$ \\
\hline 2 & $55-59$ & , & $\begin{array}{l}\text { Far } \\
\text { advanced }\end{array}$ & -5 & + & 2 & - & & 1 & $\begin{array}{l}\text { Thoracoplasty for T.B. } \\
\text { Empyema, broncho- } \\
\text { pleural fistula, spread }\end{array}$ \\
\hline 3 & $55-59$ & ", & " & $5+$ & + & 1 & + & 1 & & $\begin{array}{l}\text { Staph. infection, Semb's } \\
\text { space, septicaemia }\end{array}$ \\
\hline 4 & $50-54$ & , & Moderately & -5 & + & 1 & + & 1 & & ? Not proven \\
\hline 5 & $50-54$ & Unilateral & Far & -5 & + & 2 & + & & 1 & Cor pulmonale \\
\hline $\begin{array}{r}6 \\
7 \\
8 \\
9 \\
10\end{array}$ & $\begin{array}{l}50-54 \\
50-54 \\
50-54 \\
50-54 \\
50-54\end{array}$ & $\begin{array}{l}\text { Bilateral } \\
\quad, " \\
, " \\
, "\end{array}$ & $\begin{array}{l}\text { advanced } \\
\text {," } \\
\text {," } \\
\text {," }\end{array}$ & $\begin{array}{r}1-3 \\
5+ \\
5+ \\
5+ \\
5+\end{array}$ & $\begin{array}{l}+ \\
+ \\
+ \\
+ \\
+\end{array}$ & $\begin{array}{l}2 \\
3 \\
2 \\
2 \\
2\end{array}$ & $\begin{array}{l}+ \\
+ \\
\overrightarrow{+} \\
+\end{array}$ & $\begin{array}{l}1 \\
1 \\
1\end{array}$ & $\begin{array}{l}1 \\
1\end{array}$ & $\begin{array}{l}\text { Respiratory insufficiency } \\
\text { Post-nephrectomy } \\
\text { T.B., Semb space* } \\
\text { Respiratory insufficiency } \\
\text { Cor pulmonale }\end{array}$ \\
\hline $\begin{array}{c}\text { Pneum } \\
1 \\
2\end{array}$ & $\begin{array}{c}\text { nectomy } \\
55-59 \\
50-54\end{array}$ & $\begin{array}{l}\text { Unilateral } \\
\text { Bilateral }\end{array}$ & , & $\begin{array}{l}5+ \\
5+\end{array}$ & + & $\begin{array}{l}2 \\
1\end{array}$ & + & 1 & 1 & $\begin{array}{l}\text { Haemoptysis } 4 \text { years later } \\
\text { Respiratory insufficiency }\end{array}$ \\
\hline $\begin{array}{c}\text { Lobec } \\
1\end{array}$ & $m_{60+}$ & , & ", & $5+$ & + & 1 & - & 1 & & $\begin{array}{l}\text { Bronchopleural fistula, } \\
\text { pulmonary oedema }\end{array}$ \\
\hline $\begin{array}{c}\text { Cavern } \\
1\end{array}$ & ${ }_{55-59}$ & , & , & $5+$ & + & 3 & + & 1 & & Respiratory insufficiency \\
\hline
\end{tabular}

* Conservative and surgical treatment fail ed (Pines, 1954).

or six ribs been removed in thoracoplasty during recent years. Again, resection of lobes or segments might result in less disturbance of function than if thoracoplasty were used in indiscriminating collapse of both diseased and healthy tissue. It was used here with this in mind in patients with strictly localized disease and has achieved its purpose.

There is a tendency for the emphysematous lung, so frequent in these patients, to "creep " upwards under a thoracoplasty and to vitiate the relaxation which should be accomplished by this procedure. To combat this, a modified type of thoracoplasty (Sellors, Jackson, and Callanan, 1955) was used in certain cases, a costal roof being formed to prevent apical re-expansion. So far it has been successful.

Fatal cases are given in some detail in Table III.

If operative mortality is related to those of the 121 patients who left hospital alive, then $7 \%$ died in the first six months. Most of these deaths occurred in patients who had far advanced, long-standing disease and with invariable impairment of respiratory reserve. Six (those who died of respiratory insufficiency or cor pulmonale) were "last hope" cases, who would have died anyway and probably would not have been operated on at the present day-certainly not with modern methods both of respiratory assessment and of long-term chemotherapy.
Complications, apart from the fatal cases already discussed, were briefly as shown in Table IV. Again, the overriding importance of dyspnoea and bronchitis stands out.

\section{FoLLOW-UP}

Of the 111 patients who survived more than six months after the operation, 102 were traced, while the remaining nine eluded inquiry. The significant points which seemed to us to require elucidation were survival, whether the patient was working (including housework in women), whether he was

TABLE IV

\section{COMPLICATIONS IN SURVIVORS}

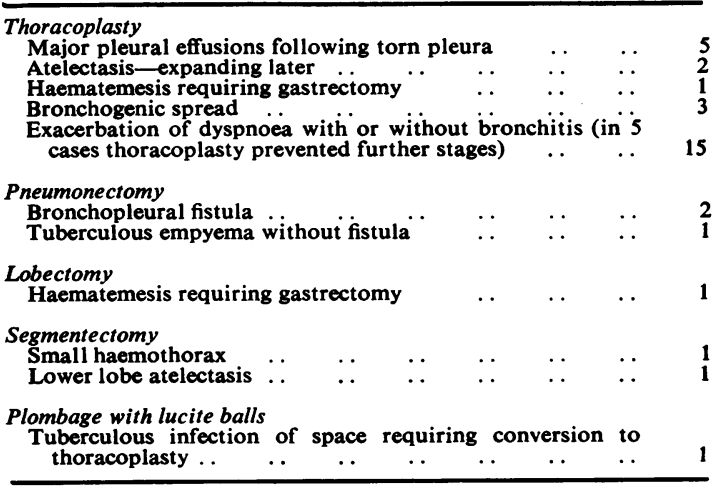


well or not and the cause of any ill-health, and lastly the state of the sputum.

The follow-up period was at least six months, and in some was as long as eight years. The patients have been divided into yearly groups according to the length of observation since operation.

TABLE V

RESULTS OF FOLLOW-UP

\begin{tabular}{|c|c|c|c|c|c|c|c|c|}
\hline \multirow{2}{*}{$\begin{array}{c}\text { Post- } \\
\text { operative } \\
\text { Follow-up } \\
\text { Period }\end{array}$} & \multirow[b]{2}{*}{ No. } & \multirow[b]{2}{*}{$\begin{array}{c}\text { Work- } \\
\text { ing }\end{array}$} & \multirow[b]{2}{*}{ Well } & \multirow[b]{2}{*}{$\begin{array}{l}\text { Un- } \\
\text { well }\end{array}$} & \multirow[b]{2}{*}{ Dead } & \multicolumn{3}{|c|}{ Sputum } \\
\hline & & & & & & $\begin{array}{c}\text { Nega- } \\
\text { tive }\end{array}$ & $\begin{array}{c}\text { Inter- } \\
\text { mit- } \\
\text { tently } \\
+ \text { ve }\end{array}$ & $\begin{array}{l}\text { Persis- } \\
\text { tently } \\
\text { + ve }\end{array}$ \\
\hline $\begin{array}{l}\text { 6-12 months } \\
1-2 \text { years.. } \\
2-3, " . . \\
3-4, \not \\
\text { Over } 4 \text { years }\end{array}$ & $\begin{array}{l}13 \\
37 \\
21 \\
15 \\
16\end{array}$ & $\begin{array}{l}4 \\
20 \\
13 \\
13 \\
12\end{array}$ & $\begin{array}{l}10 \\
26 \\
14 \\
12 \\
13\end{array}$ & $\begin{array}{r}1 \\
10 \\
6 \\
3 \\
2\end{array}$ & $\begin{array}{l}2 \\
1 \\
1 \\
0 \\
1\end{array}$ & $\begin{array}{r}9 \\
32 \\
18 \\
13 \\
14\end{array}$ & $\begin{array}{l}1 \\
2 \\
2 \\
1 \\
0\end{array}$ & $\begin{array}{l}1 \\
2 \\
0 \\
1 \\
1\end{array}$ \\
\hline Totals.. & 102 & 62 & 75 & 22 & 5 & 86 & 6 & 5 \\
\hline Percentage & & 61 & 74 & 22 & 4 & 86 & 6 & 4 \\
\hline
\end{tabular}

Of the total, $61 \%$ were working at the time of inquiry, $74 \%$ were well and some would eventually be allowed to work by their chest physicians, $22 \%$ were unwell, and $4 \%$ had died. Eighty-six per cent. were sputum negative (on direct examination and culture where the latter had been done), $6 \%$ were intermittently positive, and $4 \%$ were persistently positive.

The reasons why patients were unwell are of interest. Four were unwell because of tuberculous reactivation or because of persistent post-operative complications, and three of these were sputum positive. In a further five dyspnoea with or without bronchitis was an equally predominant factor in their clinical state, and four of these were sputum positive ; in four of these again dyspnoea and bronchitis were worse since operation.

Ten patients were sputum negative and the tuberculosis was satisfactorily controlled. These patients were disabled by dyspnoea often associated with bronchitis, and seven stated that the disability had increased since operation. One patient was incapacitated by a gastric ulcer and two by an anxiety neurosis. In only eight of these 22 unwell patients had operation failed to achieve its purpose, although it may have increased subsidiary dyspnoea or bronchitis in another seven. The true success of these operations would appear to be reflected in the $86 \%$ of the survivors who remain steadily negative and whose disease appears quiescent or arrested.

In a few patients, further treatment had to be given for reactivations on the same or opposite side. Only two patients died from tuberculous complications.

\section{The Significance of Dyspnoea and Bronchitis}

Our assessment of these can only be approximate, bearing in mind the retrospective nature of the survey, the large number of observers whose recordings were used, and also the sometimes inadequate notation of a few patients' hospital course. Nevertheless certain deductions still seem -warranted.

TABLE VI

SIGNIFICANCE OF DYSPNOEA

\begin{tabular}{|c|c|c|c|c|c|c|c|}
\hline $\begin{array}{l}\text { Dys- } \\
\text { pnoea } \\
\text { Grade }\end{array}$ & No. & $\begin{array}{l}\text { Bron- } \\
\text { chitis }\end{array}$ & $\begin{array}{l}\text { Emphy- } \\
\text { sema }\end{array}$ & $\begin{array}{c}\text { Far- } \\
\text { advanced } \\
\text { Disease }\end{array}$ & Well & $\begin{array}{l}\text { Un- } \\
\text { well }\end{array}$ & Dead \\
\hline $\begin{array}{l}0 \\
1 \\
2 \\
3\end{array}$ & $\begin{array}{c}51 \\
\text { Total }\end{array}\left\{\begin{array}{c}39 \\
18 \\
3\end{array}\right.$ & $\begin{array}{r}4 \\
19 \\
12 \\
3\end{array}$ & $\begin{array}{r}9 \\
17 \\
7 \\
2\end{array}$ & 31 & $\begin{array}{r}46 \\
23 \\
6 \\
0\end{array}$ & $\begin{array}{r}5 \\
11 \\
6 \\
0\end{array}$ & $\begin{array}{l}0 \\
5 \\
6 \\
3\end{array}$ \\
\hline
\end{tabular}

A majority of our cases had dyspnoea and this symptom was frequently associated with bronchitis and radiological evidence of emphysema. As might be expected a majority of the patients who had far advanced disease were found in the dyspnoeic group. None of the patients who had no dyspnoea died and only five of the 51 in the group are unwell. All deaths took their number from the dyspnoeic group, and, of the 22 unwell patients, 17 are from this group.

TABLE VII

INCIDENCE OF BRONCHITIS

\begin{tabular}{|c|c|c|c|c|}
\hline & No. & Died & Well & Unwell \\
\hline $\begin{array}{l}\text { Bronchitis .. } \\
\text { No bronchitis }\end{array}$ & $\begin{array}{l}38 \\
73\end{array}$ & $\left.\begin{array}{llr}\text { Post-operative } & 5 \\
\text { Late } \ldots & 3 \\
\text { Post-operative } & 4 \\
\text { Late } \quad . & 2\end{array}\right\} 8$ & $\begin{array}{l}17 \\
58\end{array}$ & $13 \begin{array}{l}\text { (10 bronchi- } \\
\text { tis worse) } \\
10 \begin{array}{l}\text { (4 dyspnoea } \\
\text { worse) }\end{array}\end{array}$ \\
\hline
\end{tabular}

Fewer patients are recorded with bronchitis than with dyspnoea. In the bronchitic group, mortality and ill-health were higher in proportion than in the non-bronchitic group, while the frequency of bronchitis increased with the degree of dyspnoea (Table VI). Bronchitis was therefore a factor of significance in prognosis though not invariably so.

At first we questioned whether bronchitis had been recorded in every patient where it had occurred, having in mind especially the smaller number of patients with bronchitis than those with dyspnoea. We had thought that bronchitis would have been an even more significant factor than it has actually appeared to be. There is, however, a 
marked difference in disability between those with recorded bronchitis and those without, and it seems deducible that only a few of the cases of significant bronchitis have escaped recording. In those who had dyspnoea without bronchitis almost all had bilateral disease and here destruction of lung tissue was probably a major factor.

TABLE VIII

INCIDENCE OF EMPHYSEMA

\begin{tabular}{|c|c|c|c|c|}
\hline & No. & Died & Well & Unwell \\
\hline $\begin{array}{c}\text { Emphysema }(14 \\
\text { bronchitis, re- } \\
\text { mainder mostly } \\
\text { bilateral T.B.) }\end{array}$ & 35 & 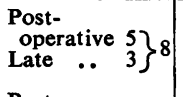 & 20 & 7 (6 dyspnoea) \\
\hline No emphysema.. & 76 & 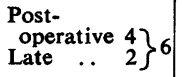 & 55 & $15(8$ \\
\hline
\end{tabular}

We have attempted a radiological diagnosis of emphysema according to the criteria of Simon and Galbraith (1953). There was a smaller proportion of patients with such evidence of emphysema as compared with those who had dyspnoea, and clinical correlation of the emphysematous group with dyspnoea as a whole was not close. It cannot be said that the radiological diagnosis of emphysema in our series was of value in estimating potential respiratory distress. But emphysema as demonstrated by more exact methods is of importance in such an assessment (Gaensler, Cugell, Lindgren, Verstraeten, Smith, and Strieder, 1955).

\section{Discussion}

Several series of patients with pulmonary tuberculosis who have been aged 50 and over have been reported, all treated by thoracoplasty (Shapiro and Munz, 1940 ; Rudolph, 1942 ; Zuelke, Adams, and Bloch, 1946). The largest series have been described by Overholt (1940) with 43 patients, Beaconsfield et al. (1954) with 55 patients, and Källqvist (1955) with 42 patients. In these series operative mortality ranged from $4.8 \%$ to $7 \%$, while sputum conversion was in the region of $80 \%$. The importance of dyspnoea and bronchitis in affecting the well-being of these patients was ignored by all these authors except the last.

That $7 \%$ of our cases died within six months of operation is not a forbidding figure. As we have emphasized earlier, most of these deaths were among "last hope" cases and, if these are left out, results were excellent in those patients who had no dyspnoea, while in the remainder, who numbered over half of the series, disease was often far advanced and dyspnoea and bronchitis added to the risks. Good results could not be expected in this latter group, but nevertheless sputum conver- sion over the whole series was $86 \%$. Surgery had achieved its primary object in most cases, but in some of these only at the price of crippling disablement. It is thus in the avoidance of these last disasters that careful clinical judgment and exact physiological assessment must be employed. In none of the patients of this series was the latter available as it is at the present time at both hospitals.

Our results in thoracoplasty, once such deaths from respiratory insufficiency are excluded, support the belief of the authors quoted that it is a procedure both practicable and with a low risk in patients over 50 . In series perhaps composed largely of younger patients operative mortality has ranged from $2 \%$ (Sellors, 1953) to $7 \%$ (Laird, 1953), 10.6\% (Morland and Price Thomas, 1952), and $12 \%$ (Edwards, Leggat, and Davies, 1941). These varying results may reflect the differing degrees of advanced disease in each series as much as any other factor (Francis, 1954), but in general their mean mortality is little different to ours.

Similarly, in lobectomy and pneumonectomy, although the numbers are small, the trend of results is close to those reported in many such series in chiefly younger patients (Chamberlain and Klopstock, 1950 ; Bickford, Edwards, Esplen, Gifford, and Thomas, 1952 ; Sellors, 1953). Resection should be more widely employed in older patients, because in these, as we have demonstrated, it is of importance to preserve as much pulmonary function as possible. Disturbance might be less, as we have mentioned, than if thoracoplasty were employed (Gaensler et al., 1955 ; Taylor, Petter, and Whittenberger, 1955), avoiding the substitution of a condition which for these patients is perhaps even more insoluble and certainly as fatal as their original disease.

We submit that surgery in patients aged 50 and over is both practicable and, in the face of the growing frequency of these patients, desirable both on humanitarian and on social grounds. Morbidity and mortality should be small if careful assessment is made beforehand. Two final reservations must be made. First, only seven of our patients were aged 60 and over and we can advance no real claims concerning patients in this age group. Such patients require careful assessment both as to their suitability for operation and to their expectation of life even if operation were successful. (Our oldest patient underwent a successful thoracoplasty at 71 years.) Lastly we have analysed a selected group, who may be unrepresentative of the whole tuberculous population, who are aged 50 and over. Nevertheless, 
even if this were shown to be true, our results show that many of this population remain suitable for surgical treatment, particularly if the number of cases we have collected from two hospitals is borne in mind.

\section{SUMMARY}

Against the greatly increasing problem of older patients with pulmonary tuberculosis is contrasted the prevailing hesitation to submit these patients to essential surgery.

One hundred and twenty patients aged 50 and over who underwent thoracic operations have been analysed. In the first six months $7 \%$ died, while only a further $4 \%$ have died later so far. Death has been related in direct proportion to the degree of dyspnoea and, to a lesser extent, to bronchitis, as well as to other well-known factors. Sputum conversion has been $86 \%$ in the survivors, but dyspnoea and bronchitis have again been prominent as a cause of disability.

It has been shown that in such patients without dyspnoea surgery can reasonably be contemplated. Those who are short of breath must be carefully assessed by clinical and physiological means as to their suitability for operation. It is probable that the wider use of resection, rather than thoracoplasty in suitable cases, would avoid excessive disturbance of respiratory function in these patients.

We are grateful to $\mathrm{Mr}$. T. Holmes Sellors, $\mathrm{Mr}$. Vernon C. Thompson, Mr. Donald Barlow, and Mr. J. R. Belcher, both for permission to study cases under their care and for their encouragement and criticism.

We are indebted to various chest physicians who helped our follow-up. This was done by each of us at our respective hospitals, and we are grateful to the secretarial staff for their help.

\section{REFERENCES}

Alling, D. W., Lincoln, N. S., and Bosworth, E. B. (1954). Amer. Rev. Tuberc., 70, 995.

Beaconsfield, P., Coulthard, H.S., and Kergin, F. G. (1954). Thorax, $9,211$.

Bickford, B. J., Edwards, F. R., Esplen, J. R., Gifford, J. H., and Thomas, O. F. (1952). Ibid., 7, 310

British Tuberculosis Association (1955). Society of Thoracic Surgeons Survey, Report at B.T.A. meeting, Cambridge, 1955.

Caplin, M., Griffiths, J. J., and Silver, C. P. (1956) Tubercle (Lond.), $37,233$.

Chamberlain, J. M., and Klopstock, R. (1950). J. thorac. Surg., 20, 843.

Edwards, F. R., Leggat, G., and Davies, H. M. (1941). Brit. med. J., 2,901 .

Ellman, P. (1956). Brit. J. Tuberc., 50, 3.

Foster-Carter, A. F., Myers, M., Goddard, D. L. H., Young, F. H., and Benjamin, B. (1952). Brompton Hosp. Rep., 21, 1.

Francis, R. S. (1954). Tubercle (Lond.), 35, 210.

Gaensler, E. A., Cugell, D. W., Lindgren, I., Verstraeten, J. M., Smith. S. S., and Strieder, J. W. (1955). J. thorac. Surg., 29, 163.

Källqvist, I. (1955). Acta tuberc. scand., 31, 1.

Laird, R. (1953). Lancet, 2, 319.

Ministère de la Santé Publique (1954). Bull. Inst. nat. Hyg. (Paris), $9,1$.

Ministry of Health (1954). Annual Report for 1953, pt. 2, p. 99. H.M.S.O., l ondon.

Mitchell, R. S. (1955). Amer. Rev. Tuberc., 72, 487.

Morland, A., and Thomas, C. Price (1952). In Diseases of the Chest, ed. Marshall, G., and Perry, K., Vol. 1, p. 415. Butterworth,

London.
National Tuberculosis Association (1950). Diagnostic Standards and Classification of Tuberculosis, 1950 edition. New York.

New York State Department of Health, Annual Report, 1954.

Overholt, R. H. (1940). Amer. Rev. Tuberc., 41, 143.

Oyama, T. (1955). Ibid., 72, 613 .

Pagel, W., Simmonds, F. A. H., and Macdonald, N. (1953). Pulmonary Tuberculosis, 3rd ed., p. 498. Oxford University Press, London.

Pines, A. (1954). Tubercle (Lond.), 35, 72.

- (1955). Ibid., 36, 319.

Registrar-General's Statistical Review of England and Wales (19401953). London.

Rudolph, C. W. (1942). Med. Bull. Veterans' Adm., 19, 1.

Sellors, T. H. (1953). Acta chir. belg., 52, 433.

Jackson, J. W., and Callanan, J. G. (1955). Thorax, 10, 191.

Shapiro, R., and Munz, C. W. (1940). Amer. Rev. Tuberc., 42, 631. Simmonds, F. A. H. (1953). Tubercle (Lond.), 34, 314.

Simon, G., and Galbraith, H. J. B. (1953). Lancet, 2, 850.

Taylor, W. J., Petter, J. B., and Whittenberger, J. L. (1955). Amer. Rev. Tuberc., 72, 453 .

Zuelke, S. E., Adams, W. E., and Bloch, R. C. (1946). Ibid., 54, 368. 